\title{
PERSYARATAN SUKSESOR DALAM GEREJA SUARA KEBENARAN INJIL (GSKI)
}

\author{
Grant Nixon \\ STT Ekumene Jakarta \\ Artha Gading Selatan no. 1 \\ grant.nixon@sttekumene.ac.id
}

\begin{abstract}
ABSTRAK
Suksesi dalam sebuah organisasi tidak dapat terlepas dari persyaratan tertentu seorang suksesor yang diharapkan sejalan dengan visi, misi, dan nilai yang diemban organisasi tersebut. Oleh sebab itu, Gereja Suara Kebenaran Injil (GSKI) sebagai sebuah organisasi harus memiliki suksesor yang akomodatif dalam mewujudkan kepentingan organisasi. Tulisan ini bertujuan untuk mendeskripsikan persyaratan-persyaratan suksesor yang akomodatif terhadap kebutuhan organisasi GSKI di masa mendatang berdasarkan temuan lapangan dan studi biblika terhadap sosok Yosua sebagai model suksesor yang berhasil. Persyaratan-persyaratan yang ditemukan diajukan sebagai sebuah rekomendasi konstruktif bagi persyaratan suksesor yang baku dan akomodatif dalam tubuh GSKI. Penelitian ini menggunakan metode kualitatif dengan pendekatan grounded theory. Teknik pengumpulan data dilakukan melalui wawancara terhadap para pemangku kepentingan dan studi pustaka. Data dianalisis dengan melakukan sintesis antara temuan dalam studi pustaka dan wawancara. Hasil sintesis antara temuan wawancara dan studi pustaka menghasilkan kerangka konseptual mengenai persyaratan suksesor yang akomodatif. Hasil analisis menunjukkan bahwa persyaratan-persyaratan suksesor GSKI yang akomodatif adalah sosok yang memiliki spiritualitas yang sehat dan konsisten, pengajar yang terdidik, gembala yang terampil dalam pastoral, organisator yang ulung serta memiliki visi peningkatan mutu organisasi secara kolektif. Simpulan dari penelitian ini adalah persyaratan suksesor GSKI di masa mendatang beririsan tebal dengan kualitas diri pemimpin GSKI kini. Tercapainya hal ini sangat dipengaruhi oleh proses mentoring dan pemberdayaan yang efektif.
\end{abstract}

Kata kunci: gereja, Gereja Suara Kebenaran Injil, Perjanjian Lama; suksesor; Yosua

\section{ABSTRACT}

Succession in an organization cannot be separated from certain requirements of a successor that is expected to be in line with the organization's vision, mission, and values. Therefore, Gereja Suara Kebenaran Injil (GSKI) as an organization must have a description of the successor's accommodative requirements in realizing the interests of the organization in the future. This paper aims to describe the successor requirements that are accommodating to the needs of the GSKI organization in the future based on field findings and a biblical study of Joshua as a successful successor model. The requirements found were proposed as a constructive recommendation for the standard and accommodating successor requirements within the GSKI body. This research uses a qualitative method with a grounded theory approach. Data collection techniques were carried out through interviews with stakeholders and literature studies. Data were analyzed by synthesizing the findings in the literature study and interviews. The synthesis between interview findings and literature study produced a conceptual framework regarding accommodative successor requirements. The analysis shows that the requirements of accommodative GSKI successors are those who have a healthy and consistent spirituality, educated teachers, pastors who are skilled in pastoral care, accomplished organizers and person who has the vision to improve organizational quality collectively. This research concludes that the requirements of 
the GSKI successors in the future are deeply intersected with the quality of the present GSKI leader. Achieving this is greatly influenced by an effective mentoring and empowerment process.

This paper specifically presents a critique of the conflicting ideas of Fideism and Secularism about the use of faith and thought. Indications of the debate between the mind devotees and the faith devotees, appears until now. There are groups who believe that the Word is received only by faith and does not require the mind roles. The mind is seen as an obstacle in receiving God's Word. There are also groups who believe that all the true Word is the Word that makes sense. Things that are supernatural or unacceptable to logic, are seen as unimportant. This paper aims to provide a critique of the views of Fideism and Secularism, which contradict each other in the use of mind and faith. This paper also aims to show the relationship between mind and faith. The method used in this study is the study of literature, and the study of theological meaning about mind and faith to find the relationship between mind and faith.

Keywords; mind, faith, fideism, secularism

\section{PENDAHULUAN}

Suksesi kepemimpinan adalah suatu bagian integral dalam sebuah organisasi (Akinyele, Ogbari, Akinyele, \& Dibia, 2015). Suksesi kepemimpinan terkait erat dengan persyaratan-persyaratan seorang suksesor yang dipandang akomodatif terhadap kepentingan organisasi yang di dalamnya terdapat para pemangku kepentingan (Gowthami, 2012). Persyaratan yang dipandang akomodatif terhadap kepentingan organisasi tertuang dalam sebuah rencana suksesi (succession plan) (Gordon \& Overbey, 2018). Persyaratan suksesor secara umum berkaitan erat dengan kompetensi secara pengetahuan maupun keterampilan dan kemampuan dalam kepemimpinan untuk menjalankan roda organisasi (Gowthami, 2012).

Gereja Suara Kebenaran Injil (selanjutnya disingkat "GSKI”) adalah sebuah sinode gereja di Indonesia yang secara resmi berdiri pada 3 Desember 2018. Diungkapkan oleh Sekretaris Umum GSKI, Kornelis Kiong, GSKI belum memiliki rumusan perencanaan suksesi yang di dalamnya terdapat persyaratan suksesor. Hal ini terjadi kepada 74\% dari 381 organisasi non-profit dunia (Santora, Sarros, Bozer, Esposito, \& Bassi 2015 dalam Byers \& Byers, 2016). Gagalnya perencanaan suksesi dalam suatu organisasi non-profit (termasuk di dalamnya organisasi keagamaan), menunjukkan pengalaman kegagalan dalam mempertahankan stabilitas organisasi, finansial, pergeseran misi organisasi (Byers \& Byers, 2016). Mengingat pentingnya perencanaan suksesi untuk menjamin keberlangsungan dan keberhasilan jangka panjang sebuah organisasi (Wolf, 2006 dalam Gowthami, 2012), maka peneliti sebagai bagian dari GSKI memandang penting untuk mengambil bagian secara konstruktif dalam perencanaan suksesi bagi GSKI. 
Salah satu komponen penting dalam perencanaan suksesi adalah persyaratan suksesor untuk menemukan sosok yang tepat (Santora, Sarros, \& Esposito, 2013). Artikel ini secara spesifik bertujuan mendeskripsikan persyaratan suksesor yang mengakomodasi kepentingan GSKI dalam rangka membangun perencanaan suksesi. Persyaratan suksesor yang ditemukan dapat dimanfaatkan pada masa mendatang sebagai salah satu rekomendasi model persyaratan suksesor GSKI. Menimbang luasnya pembahasan mengenai perencanaan suksesi kepemimpinan, pembahasan komponen lain dalam perencanaan suksesi dalam GSKI akan dilakukan pada penelitian berbeda dalam lingkup yang spesifik pula.

\section{METODE}

Metode penelitian yang digunakan dalam artikel ini adalah kualitatif. Metode kualitatif dipilih karena penelitian yang diadakan bertujuan untuk mengeksplorasi sebuah ide atau konsep baru dengan peneliti sebagai instrumen utamanya (Yin, 2014 dalam Toliver, 2017). Pendekatan kualitatif yang digunakan adalah grounded theory. Grounded theory adalah pendekatan yang mengumpulkan data melalui berbagai teknik pengumpulan data seperti observasi, wawancara, dan berbagai pengamatan yang teliti terhadap sebuah fenomena guna mengonstruksi teori berdasarkan fakta empiris (Pongtiku, 2019). Data lapangan yang telah terkumpul, dianalisis bersama dengan teori sebelumnya untuk menghasilkan sebuah teori yang relevan dan mutakhir dengan data lapangan tersebut (teoritisasi data). Dalam penelitian ini, teori yang hendak dikonstruksi dari data wawancara adalah persyaratan suksesor GSKI.

Teknik pengumpulan data dilakukan melalui wawancara dan studi pustaka. Studi pustaka dilakukan guna membangun landasan teori yang berasal dari penelitianpenelitian sebelumnya yang relevan dengan persyaratan seorang suksesor. Di samping itu, studi pustaka secara biblika dilakukan guna mengeksplorasi referensi biblika terhadap model suksesor pemimpin umat yang ideal. Eksplorasi dilakukan terhadap sosok Yosua yang menjadi berhasil menjadi suksesor Musa. Pada bagian ini, karakterkarakter Yosua diuraikan secara sistematis untuk melihat faktor-faktor apa saja yang terdapat dalam diri Yosua, sehingga ia berhasil meneruskan kepemimpinan Musa. Faktor-faktor tersebut dapat diserap dan diimplementasikan dalam proses suksesi di 
tubuh GSKI. Studi pustaka dilakukan memanfaatkan sumber-sumber daring dan buku teks yang berkisar pada kepemimpinan dan suksesi kepemimpinan.

Data lapangan dikumpulkan dengan melakukan wawancara pertanyaan terbuka melalui asesmen daring dengan anggota Badan Pengurus Pusat Gereja Suara Kebenaran Injil (BPP GSKI), aktivis cabang GSKI Rehobot Mal Artha Gading (GSKI MAG), dan jemaat GSKI. Pertanyaan yang diajukan berkisar pada persyaratan apa saja yang dibutuhkan seorang pemimpin sinode GSKI di masa mendatang. Persyaratan yang dimaksud mencakup aspek kompetensi pribadi, spiritualitas, dan kepemimpinan organisasional.

Wawancara pertama-tama dilakukan terhadap anggota BPP GSKI karena anggota BPP GSKI adalah pemangku kepentingan internal yang secara langsung menjalankan roda organisasi. Selanjutnya, wawancara dilakukan dengan lapisan kedua yang menjalankan organisasi GSKI MAG pada tingkat gereja lokal otonomi, yakni kepada para aktivis gereja lokal. Pada tingkat terakhir, wawancara dilakukan terhadap jemaat GSKI yang tidak terlibat dalam pengurus gereja lokal guna memperoleh dukungan data mengenai pemimpin sinode yang ideal.

Pada akhirnya, data wawancara dan data yang diperoleh melalui studi pustaka disintesis secara kualitatif oleh peneliti untuk memperoleh persyaratan-persyaratan yang akomodatif terhadap suksesor sinode GSKI. Hasil dan pembahasan dalam artikel ini disajikan terlebih dahulu dalam landasan teori, kemudian penjabaran temuan lapangan melalui wawancara mendalam. Setelah landasan teori dan temuan lapangan dipaparkan, maka akan dilakukan sintesis untuk memperoleh deskripsi persyaratan suksesor GSKI. Pada bagian akhir akan disimpulkan hasil penelitian dalam bagian "simpulan".

\section{HASIL DAN PEMBAHASAN}

\section{Kepemimpinan}

- Pengertian Kepemimpinan

Kepemimpinan adalah usaha mengarahkan individu atau kelompok mencapai tujuan yang telah disepakati bersama (Barna, 2009 dalam Parapat, Sabdono, Andreas, \& Wurjanto, 2020). Melengkapi definisi kepemimpinan ini, Oswald Sanders menyatakan bahwa kepemimpinan berbicara mengenai pengaruh (Sanders, 2007). Maxwell sepaham dengan pemahaman Sanders bahwa kepemimpinan berada dalam ruang lingkup pengaruh (Maxwell, 
2013). Dapat disimpulkan bahwa kepemimpinan adalah seni mempengaruhi individu atau kelompok untuk mencapai tujuan tertentu.

- Faktor-faktor Penting dalam Kepemimpinan

Sanders dalam perspektif Paulus, mengemukakan bahwa paling tidak ada enam aspek persyaratan (kualifikasi) utama yang harus dimiliki oleh seorang pemimpin, yakni kualifikasi sosial, kualifikasi moral, kualifikasi mental, kualifikasi kepribadian, kualifikasi domestik, dan kedewasaan (2007). Enam hal ini menjadi faktor utama keberhasilan sebuah kepemimpinan. Sedangkan Maxwell secara terperinci mengajukan 21 ciri pokok seorang pemimpin yang ia pandang sebagai faktor penting dalam kepemimpinan. Ciri-ciri pokok tersebut ialah: karakter, karisma, komitmen, komunikasi, kompetensi, keberanian, ketajaman, fokus, kemurahan hati, inisiatif, kemampuan mendengarkan, semangat yang tinggi, sikap positif, kemampuan memecahkan masalah, kemampuan menjalin hubungan, tanggung jawab, perasaan aman, disiplin pribadi, pelayanan, sikap mau belajar, dan impian (Maxwell, 2014).

\section{Suksesi Kepemimpinan}

- Pengertian Suksesi Kepemimpinan

Suksesi (kepemimpinan) menurut KBBI adalah "penggantian (terutama di lingkungan pimpinan tertinggi negara) karena pewarisan" atau "proses pergantian kepemimpinan sesuai dengan peraturan perundang-undangan yang berlaku" (Suksesi, KBBI, 2020). Secara umum, suksesi dipahami sebagai sebuah usaha sistematis untuk membantu pemimpin yang perlu mengidentifikasi, mengembangkan, dan memilih pemimpin masa depan dalam kumpulan kandidat-kandidat yang berpotensi secara adil (Mehrabani, 2013).

- Ruang Lingkup Suksesi Kepemimpinan

Menurut Mehrabani, suksesi kepemimpinan tidak dapat disederhanakan hanya dalam lingkup 'mengganti' pemimpin. Dalam dunia modern dengan dinamisitas yang tinggi dan tidak terprediksi, suksesi kepemimpinan harus diadakan dalam ruang lingkup penemuan akan sekelompok orang dengan potensi yang besar dalam setiap jenjang organisasi (Mehrabani, 2013). Mendukung Mehrabani, Akinyele menemukan dalam studinya bahwa lingkup suksesi kepemimpinan mencakup prediksi terhadap posisi yang berpotensi mengalami krisis kepemimpinan, pengembangan kelompok individu yang berpotensi, dan pemilihan orang yang tepat sesuai kebutuhan posisi yang mengalami krisis(2015). Dengan demikian, ruang lingkup suksesi kepemimpinan merujuk pada pencarian orang-orang berpotensi tinggi, pengembangan kompetensi orang-orang tersebut, dan menciptakan peluang kepemimpinan bagi mereka dalam setiap jenjang organisasi. Latar belakang individu dan identitas individu tidak lagi menjadi lingkup utama suksesi, melainkan beralih pada 
lingkup kompetensi dan kemampuan memimpin individu. Akinyele menyimpulkan bahwa suksesi kepemimpinan adalah sebuah proses mendetil yang pada intinya tercakup proses transisi pengetahuan organisasi, memori organisasi, dan keberlangsungannya (2015).

- Urgensi Suksesi Kepemimpinan

Suksesi kepemimpinan harus dipandang sebagai sebuah proses mendesak yang perlu dikerjakan sedini mungkin (Gordon \& Overbey, 2018). Studi menunjukkan sebuah organisasi dalam skala kecil berjuang keras bahkan runtuh tanpa adanya suksesi kepemimpinan yang terencana (Haword, 2005 dalam Gordon \& Overbey, 2018). Suksesi kepemimpinan terbukti memfasilitasi sebuah organisasi untuk mengambil langkah-langkah strategis kepada pengembangan kepemimpinan, kemampuan, dan kepercayaan diri anggotanya (Oluwaseun Oduwusi, 2018). Oleh karenanya, tidak berlebihan jika dikatakan bahwa suksesi kepemimpinan adalah isu penting dalam pengelolaan sumber daya manusia (Mehrabani, 2013).

\section{Suksesor}

- Pengertian Suksesor

Dalam artikel ini, suksesor menunjuk pada individu atau kelompok yang melanjutkan keberlangsungan organisasi dari pendahulunya. Lowler dan Worley (2011) mengemukakan bahwa suksesor adalah bagian penting dari identitas jangka panjang sebuah organisasi (Gordon \& Overbey, 2018). Para suksesor adalah oknum yang melanjutkan dan mengembangkan visi, misi, nilai, tujuan, dan operasional organisasi.

\section{Kajian Alkitabiah terhadap Yosua sebagai Model Suksesor Ideal}

Setiap organisasi memiliki model suksesor yang dipandang akomodatif terhadap kepentingan organisasi dan diusahakan melalui berbagai langkah (Oluwaseun Oduwusi, 2018). Model suksesor bagi sebuah organisasi pertama-tama sangat ditentukan oleh jenis organisasi tersebut, yakni profit atau non-profit. Terdapat irisan yang tebal antara model suksesor organisasi profit dan non-profit. Akan tetapi, tidak dapat dipungkiri bahwa model suksesor organisasi non-profit -terutama organisasi keagamaan gereja dalam konteks ini- memiliki kriteria yang transendental, yakni kualitas spiritualitas dan legitimasi ilahi atas sosok suksesor tersebut (Frank, 1998 dalam Ishola \& Wojuola, 2019). Hal ini berangkat dari akar kepercayaan distingtif yang menciptakan perbedaan pola kepemimpinan dalam kekristenan dan organisasi umum lainnya, yakni Alkitab yang diyakini sebagai wahyu Allah atas kehendak-Nya. Alkitab dipandang sebagai dasar dan pola di mana semua organisasi Kristen berpijak serta membangun dirinya, sehingga pandangan Alkitab terhadap suksesor penting untuk diperhatikan. 
Salah satu suksesor yang menunjukkan hasil positif dan adaptif terhadap proses transisi kepemimpinan adalah Yosua. Pada bagian ini kisah Yosua akan dideskripsikan secara naratif untuk kemudian ditemukan faktor-faktor keberhasilan Yosua sebagai suksesor Musa.Yosua (Ibr. pertama kali muncul pada kisah orang Israel yang mengalami kehausan di Rafidim (Kel. 17). Kisah hidup Yosua terbagi atas dua bagian besar, yakni masa ia menjadi pelayan Musa dan masa pascakematian Musa sebagai suksesornya. Yosua digambarkan oleh narator sebagai sosok yang sangat dekat dengan Musa (Kel. 24:13; 33:11). Keterlibatan Yosua dalam perjumpaan Musa dengan Allah dan pelayanannya terhadap Musa secara tidak langsung menunjukkan sebuah proses mentoring yang intensif.

Mentoring dapat dipahami sebagai proses pendampingan dari pendahulu terhadap suksesor yang di dalamnya terjadi relasi, interaksi, dan transfer pengetahuan yang meliputi visi, misi, dan nilai-nilai (Toliver, 2017). Groves meyakini bahwa proses mentoring terhadap calon suksesor membawa dampak positif yang signifikanterhadap aspek psikososial dan pengembangan diri (2007). Luaran dari proses mentoring adalah duplikasi yang berujung pada pewarisan hal-hal berharga serta worldview pendahulu.

Proses mentoring Musa terhadap Yosua tidak hanya terjadi dalam nuansa kepemimpinan secara umum saja, melainkan dalam konteks kemiliteran pula (Dummond, 2016 dalam Parapat et al., 2020). Dengan terlibatnya Yosua sebagai pelayan Musa pada konteks militer dalam jangka waktu sekitar 40 tahun, maka terdapat cukup waktu baginya mewarisi pengetahuan dan nilai yang dimiliki Musa dalam kemiliteran secara menyeluruh (Parapat et al., 2020). Di samping itu, tidak diragukan bahwa telah terjalin komunikasi yang terbuka antara Musa dan Yosua, sehingga Yosua dapat meneruskan apa yang dirancangkan oleh Musa (Bil. 17:10). Oleh karenanya wajar apabila pada masa kepemimpinannya, Yosua menunjukkan duplikasi pola kepemimpinan seperti yang dilakukan Musa. Seperti misalnya, pola pengintaian (Yos. 2), target daerah kekuasaan (Yos. 11:23), dan orientasi kepemimpinan yang berpusat pada Allah (Yos. 24:15). Hal ini adalah hasil mentoring intensif yang dilakukan Musa terhadap Yosua melalui pendampingan dan pemberdayaan dalam jangka waktu yang panjang selama berada di padang gurun. Sehingga, keterbukaan dan pengalaman terhadap proses mentoring menjadi hal pertama yang mendukung keberhasilan Yosua sebagai suksesor.

Ia tercatat sebagai satu dari antara 12 pengintai dengan nama Hosea bin Nun (Bil. 13:8). Dalam tugas tersebut, para pengintai ditugaskan untuk memeriksa dan melaporkan bagaimana kondisi tanah yang akan mereka masuki. Pengintaian ini berakhir dengan hasil yang manis sekaligus pahit, karena mereka melihat kekuatan kota dan orang-orang yang ada di dalamnya. Berbeda dengan sepuluh pengintai lainnya, Yosua dan Kaleb melihat kemenangan terhadap kota tersebut adalah sebuah kemungkinan mengingat keyakinan atas penyertaan Allah terhadap 
bangsa Israel. Karena sikap yang diambil oleh Yosua dan Kaleb, mereka menjadi individu satusatunya dalam angkatan mereka yang bertahan sampai masuk dalam tanah Kanaan (Kel. 26:63$65)$.

Satu-satunya yang membedakan Yosua dan Kaleb dengan para pengintai lainnya adalah kemampuannya dalam melihat pengaruh keberpihakan Allah terhadap kemenangan bangsa tersebut (Bil. 14:8). Hal ini berbicara mengenai daya analisis yang baik terhadap kemampuan dan kelemahan diri di hadapan lawan. Gary Yukl menandaskan bahwa pemimpin yang efektif mampu menganalisis situasi dan mengidentifikasi tindakan yang relevan untuk dilakukan (2012). Yosua dan Kaleb mampu melihat dengan objektif -berdasarkan pengalaman empiris yang dilalui orang Israel- bagaimana kekuatan mereka di hadapan orang Kanaan. Daya analisis terhadap kekuatan, kelemahan, peluang, dan ancaman sangat penting untuk dimiliki seorang pemimpin pada masa di mana perubahan dan disrupsi sangat mudah terjadi.

Daya analisis yang berimbang menciptakan tipikal pemimpin yang adaptif terhadap perubahan. Kemampuan Yosua dalam menguasai keadaan orang Israel pada masa transisi kepemimpinannya (Yos. 1:12-18) menunjukkan keberhasilannya dalam melihat diri dan keberadaannya di tengah orang Israel. Daya analisis Yosua nampak jelas dalam strategi-strategi militer yang berujung pada penaklukkan daerah-daerah Kanaan. Faktor terbesar yang selalu ditonjolkan dalam narasi kepemimpinan Yosua sebagai faktor penentu kemenangannya adalah keberpihakan Allah (Yos. 6:27; 7:7-9). Yosua secara transenden mengakui otoritas Allah atas Israel dan menjadikannya keunggulan terbesar bagi orang Israel. Kemampuan Yosua melihat keunggulan transendental ini dapat diperhitungkan sebagai daya analisis Yosua yang tidak dimiliki oleh sepuluh calon suksesor lainnya. Daya analisis dapat digolongkan sebagai keterampilan konseptual yang harus dimiliki seorang pemimpin seperti yang dikemukakan oleh Yukl (2012).

Pada bagian akhir narasi Yosua sebagai pelayan Musa, digambarkan proses transisi kepemimpinan positif terhadapnya. Sebelum kematian Musa (Yos. 1:1), beberapa bagian mencatat bahwa dirinya ditunjuk Allah secara langsung sebagai pengganti dari Musa (Kel. 27:18; 32:28; 34:17; Ul. 1:38; 3:28; 31:3, 7, 23: 34:9). Ia memperoleh petunjuk ilahi dan peneguhan secara langsung seperti yang dialami oleh Musa pada awal kepemimpinannya (Yos. 1:1, 5). Sebagaimana Musa memimpin bangsa Israel keluar dari Mesir, Yosua memimpin bangsa Israel masuk dalam tanah Kanaan. Nampak secara kanonis, adanya usaha membuat pola penyejajaran sosok Yosua dan Musa sebagai legitimasi penulis terhadap kepemimpinan Yosua (Younger, 2000).

Berkaitan dengan hal ini, pembacaan yang mendalam terhadap narasi Yosua menghasilkan potret Yosua yang melebihi seorang suksesor biasa, kendati tetap terdapat 
perbedaan antara Musa sebagai pemimpin pertama dan Yosua sebagai penerusnya (Ramsey, 1992). Brevard S. Child berpendapat bahwa Yosua tidak hanya digambarkan sebagai suksesor biasa, melainkan dapat juga dilihat sebagai antitipe dari Musa (Child, 1979, hal. 245). Hal ini dapat terlihat dari berbagai adegan narasi seperti: Allah yang berulang kali menjamin penyertaan-Nya seperti yang dilakukan terhadap Musa (Yos. 1:5; 3:7), penyeberangan sungai Yordan yang digambarkan secara analogis dengan penyeberangan Laut Teberau (Yos. 4:23), perjumpaan Yosua dengan Panglima Balatentara TUHAN (Yos. 5:13-15) yang analogi dengan perjumpaan Musa dengan Malaikat TUHAN di semak berapi (Kel. 3:2-5), otoritas Yosua dalam menyuarakan pesan ilahi (Yos. 6:17; 8:27), perbandingan antara tindakan militer Yosua (Yos. 724) dengan Musa, serta pada akhir kematiannya yang menunjukkan bahwa ia hamba TUHAN (Yos. 24:29) seperti yang biasa dikenakan kepada Musa (Yos. 1:1; 8:31) (Ramsey, 1992).

Hal yang perlu digarisbawahi berkaitan dengan kualitas diri Yosua sebagai suksesor Musa berkaitan erat dengan spiritualitas yang ia warisi dari Musa. Yosua tidak hanya menyerap teknik militer dan ciri khas kepemimpinan Musa. Lebih dari itu, ia dicatat sebagai orang yang dekat dengan Allah. Ia ditunjuk oleh Allah dan disertai oleh Allah. Sepanjang narasi kehidupannya, tidak tercatat cela yang mempertanyakan kualitas spiritualitasnya. Kualitas spiritualitas tidak hanya mencakup hal yang transenden dan tidak terukur, tetapi integritas dan loyalitas yang kokoh terhadap TUHAN Israel serta bangsanya. Sebaliknya seperti yang telah dinyatakan sebelumnya, nampak usaha narator untuk menyandingkan sosok Musa dan Yosua sebagai tipe dan antitipe. Dalam hal ini, dapat ditarik sebuah faktor penting dalam diri Yosua yang menentukan keberhasilannya menjadi seorang suksesor, yakni kualitas spiritualitas yang konsisten.

Berdasarkan analisis naratif terhadap kehidupan Yosua, dapat ditarik tiga faktor penting yang mempengaruhi Yosua sebagai suksesor sebuah umat. Pertama, Yosua mengalami proses mentoring dan duplikasi yang signifikan. Kedua, Yosua memiliki kualitas kompetensi diri berupa daya analisis yang baik dalam konteks memutuskan pertimbangan secara bijak dan adaptif melalui perubahan yang terjadi. Ketiga, faktor konsistensi dalam spiritualitas menjadi faktor pendorong yang tidak kalah penting dan paling ditonjolkan narasi Alkitabiah.

\section{Temuan Lapangan}

Berikut dipaparkan temuan lapangan sebagai konfirmasi empiris terhadap persyaratan suksesor yang dipandang penting dalam GSKI. Wawancara dilakukan secara daring terhadap 68 narasumber yang terdiri dari 39 orang aktivis gereja lokal GSKI, 8 orang pengurus BPP GSKI, dan 24 jemaat GSKI dari berbagai gereja lokal di bawah naungan GSKI. Dari 39 aktivis GSKI dan 8 pengurus BPP GSKI, 3 orang terhisab di antara keduanya. Wawancara dilakukan dengan 
instrumen Google Form yang disebar secara daring dengan jenis pertanyaan terbuka. Hasil temuan dideskripsikan sebagai berikut:

Dari hasil wawancara, ketiga golongan narasumber sepakat bahwa GSKI memerlukan rencana suksesi kepemimpinan. Alasan yang diajukan cukup beragam, namun yang dominan berkaitan dengan keberlangsungan dan stabilitas organisasi jangka panjang. Berkaitan dengan kelayakan dan kinerja ketua sinode GSKI, seluruh narasumber memandang bahwa ketua sinode telah memenuhi kriteria kelayakan dan kinerja sebagai ketua sinode. Mayoritas narasumber mengukur kelayakan dan kinerja tersebut dari segi spiritualitas dan kepribadian yang dapat diteladani sebagai seorang pemimpin organisasi agama. Sebagian kecil narasumber memberi catatan kecil terhadap aspek teknis organisasional yang telah berlangsung.

Bertalian dengan pendapat mengenai kualitas kandidat suksesor GSKI, mayoritas besar narasumber menyatakan belum mengidentifikasi adanya pemimpin yang memiliki kualitas setara ataupun lebih dari ketua sinode GSKI pada hari ini. Hal ini dapat dipandang sebagai mendesaknya perencanaan suksesi, terutama persiapan suksesor pada tingkat kepemimpinan atas. Berkaitan dengan hal ini, kualitas organisasi pada masa mendatang yang diharapkan segera ditingkatkan adalah manajemen organisasi yang terstruktur dalam hal pelaksanaan organisasi serta keuangan, penempatan sumber daya manusia yang baik, dan adanya proses suksesi pada setiap tingkat manajemen organisasi.

Temuan lapangan mengenai persyaratan suksesor GSKI, dideskripsikan menurut kluster anggota BPP GSKI dan aktivis gereja lokal GSKI MAG dengan tiga butir pertanyaan dengan skala umum, yakni kompetensi, spiritualitas, dan kualitas pengelolaan organisasi.Tiga kategori pertanyaan tersebut diberikan sebagai panduan bagi para narasumber dalam menjelaskan lebih detil bagaimana kriteria suksesor yang ideal bagi GSKI. Setelah diadakan wawancara, diperoleh jawaban-jawaban beriris yang spesifik mengenai suksesor ideal bagi GSKI, sebagai berikut: (1) Pada aspek kompetensi, kompetensi yang diharapkan mencakup tingkat pendidikan yang memadai, kecakapan dalam mengajar dan berteologi, serta keterampilan pastoral. (2) Spiritualitas mencakup karakter yang bersih, kehidupan intim dengan Tuhan melalui doa, inspiratif dalam kehidupan iman, dan kemampuan membuat keputusan dalam pimpinan Roh. (3) Kualitas pengelolaan organisasi yang dipandang patut dimiliki oleh suksesor GSKI adalah kemampuan mengelola organisasi secara struktural, manajemen konflik yang baik, kepemimpinan yang delegatif, efektif (dalam hal SDM), dan efisien, serta mampu menjalin kerja sama dengan berbagai pihak. Dalam data yang dianalisis terdapat indikasi kuat bahwa mayoritas narasumber menggunakan sosok ketua sinode masa ini sebagai acuan bagi suksesornya di masa mendatang. 


\section{Sintesis Kajian Alkitabiah dan Temuan Lapangan}

Berdasarkan kajian Alkitabiah dan temuan lapangan, diperoleh empat persyaratan standar bagi suksesor GSKI. Pertama, suksesor GSKI adalah seorang yang memiliki spiritualitas yang sehat dan konsisten. Hal ini paralel dengan yang disampaikan Patrick Nullens dalam artikelnya mengenai meningkatnya ketertarikan terhadap spiritualitas seorang pemimpin (2013). Spiritualitas yang sehat dan konsisten ini ditandai dengan hubungan vertikal yang harmonis dengan Allah dan horizontal antara pemimpin dengan pemimpin organisasi lainnya, pemimpin dengan anggota internal, serta pemimpin dengan jemaat pada umumnya. Karakter yang bersih juga menjadi salah satu indikator spiritualitas yang diyakini sebagai persyaratan penting bagi suksesor GSKI.

Kedua, suksesor GSKI diharapkan seorang yang memiliki kompetensi yang memadai sebagai seorang pengajar, gembala, dan organisatoris. Kompetensi di sini diukur dengan kecakapan berteologi, keterampilan pastoral, jenjang pendidikan yang memadai, dan pengalaman organisatoris yang mumpuni. Menimbang pergerakan dunia yang tidak menentu, suksesor GSKI harus seorang yang jeli dan mampu menganalisis keadaan dengan baik untuk menentukan arah organisasi ke depan (Berlinger, 2003; Susan, 2009). Arah yang dimaksud bukan hanya arah secara organisasi, tetapi penyajian ajaran dan teologi yang menjawab tantangan zaman.

Ketiga, suksesor GSKI adalah seorang yang memiliki pengalaman berorganisasi dalam internal GSKI. Seperti yang ditemukan pada lapangan, diharapkan suksesor GSKI adalah sosok yang tidak jauh berbeda dari ketua sinode sekarang. Hal ini hanya dapat terjadi melalui proses pendampingan, pemberdayaan, serta duplikasi seperti yang dialami oleh Yosua dari Musa. Dengan suksesor yang berasal dari kalangan internal, diharapkan dapat melanjutkan pola-pola kepemimpinan yang baik seperti yang tercermin dari ketua sinode. Hal ini didasarkan pada fakta bahwa temuan lapangan mayoritas mengharapkan suksesor yang paling tidak sekualitas dengan pemimpin saat ini. Santora, Sarros, dan Esposito juga mengemukakan hal yang sama dalam temuan penelitiannya terhadap organisasi non-profit selama lebih dari 30 tahun (2013).

Terakhir, suksesor GSKI adalah seorang yang memiliki pemikiran terstruktur bertalian dengan peningkatan dan perbaikan mutu organisasi. Beaumont mengalimatkan 
kriteria ini sebagai strategy and vision (2009). Mayoritas respons yang diperoleh dari anggota BPP dan aktivis gereja lokal, mengharapkan sosok suksesor yang dapat melihat masalah organisasi, merencanakan perbaikan dan peningkatan mutu, serta mengeksekusinya dalam sebuah kerja tim yang strategis. Oleh karenanya sangat baik apabila suksesor GSKI tidak hanya berkualifikasi baik secara individu, namun juga strategis dalam peningkatan dan perbaikan mutu organisasi.

\section{SIMPULAN}

Dapat disimpulkan bahwa persyaratan suksesor GSKI berada dalam perbandingan dengan ketua sinode kini. Aspek spiritualitas, kompetensi, dan keterampilan yang diharapkan beririsan tebal dengan kualitas ketua sinode GSKI kini. Adapun catatan kecil yang diberikan terhadap seorang suksesor adalah kemampuan mengorganisasi secara terstruktur dan kolektif untuk meningkatkan mutu organisasi. Tercapainya hal ini sangat dipengaruhi oleh proses mentoring intensif dan pemberdayaan terhadap kandidat-kandidat yang berpotensi. Dengan demikian, peneliti mengajukan saran konstruktif berupa peningkatan kualitas mentoring dan pemberdayaan yang lebih efektif melalui rencana-rencana terstruktur, tanpa mengabaikan nilai-nilai transendental dalam pengelolaan organisasi gerejawi.

\section{DAFTAR PUSTAKA}

Akinyele, S. T., Ogbari, M., Akinyele, F. A., \& Dibia, K. (2015). Succession Planning and Its Impact on Organizational Survival. Jorind, 13(2).

Berlinger, L. R. (2003). 91 the behavioral competency approach to effective ecclesial leadership 1 lisa r. berlinger, 2(2), 91-113.

Byers, L., \& Byers, L. (2016). Succession Planning Strategies of Faith-Based, Nonprofit Leaders of the Boomer Generation This is to certify that the doctoral study by, (April). https://doi.org/10.13140/RG.2.1.3171.1608

Child, B. S. (1979). Introduction to The Old Testament as A Scripture.

Gordon, P. A., \& Overbey, J. A. (2018). Succession planning: Promoting organizational sustainability. Succession Planning: Promoting Organizational Sustainability, (June), 1-242. https://doi.org/10.1007/978-3-319-72532-1 
Gowthami, C. (2012). Succession Planning a Need or a Necessity - a Global Perspective. International Journal of Management, IT and Engineering, 2(9), 341352. Diambil dari http://www.ijmra.us/project doc/IJMIE_SEPTEMBER2012/IJMRA-MIE1756.pdf

Groves, K. S. (2007). Integrating leadership development and succession planning best practices. Journal of Management Development, 26(3), 239-260. https://doi.org/10.1108/02621710710732146

Ishola, S. A., \& Wojuola, K. T. (2019). Jethro-Moses Model of Leadership : A Lesson for Effective Leadership in Church and Secular Organizations, (6), 42-47.

KBBI. (2020). Kamus Besar Bahasa Indonesia.

Maxwell, J. C. (2013). 21 Hukum Kepemimpinan Sejati. Jakarta: Immanuel.

Maxwell, J. C. (2014). The Indispensable Qualities of A Leader: 21 Ciri Pokok Seorang Pemimpin. (E. M. Tanuadji, Ed.). Surabaya: PT MIC.

Mehrabani, S. (2013). Succession Planning: A Necessary Process in Today's Organization. International Journal of e-Education, e-Business, e-Management and e-Learning, 1(5). https://doi.org/10.7763/ijeeee.2011.v1.61

Nullens, P. (2013). Towards a spirituality of public leadership: Engaging dietrich bonhoefffer. International Journal of Public Theology, 7(1), 91-113. https://doi.org/10.1163/15697320-12341268

Oluwaseun Oduwusi, O. (2018). Succession Planning as a Key to Effective Managerial Transition Process in Corporate Organizations. American Journal of Management Science and Engineering, 3(1), 1. https://doi.org/10.11648/j.ajmse.20180301.11

Parapat, Y., Sabdono, E., Andreas, M., \& Wurjanto, A. (2020). Moses Leadership Transition - A Moses Leadership Transition Model - A Successful Succession Management Model, 5(4).

Pongtiku, A. (2019). Grounded Theory: Step by Step. In Metode Penelitian: Tradisi Kualitatif. Jakarta: In Media.

Ramsey, G. W. (1992). Joshua (Person). In The Anchor Yale Bible Dictionary. Doubleday.

Sanders, J. O. (2007). Spiritual Leadership. Chicago.

Santora, J. C., Sarros, J. C., \& Esposito, M. (2013). Nonprofit founders and succession: How to ensure an effective leadership handover. Development and Learning in 
Organizations, 28(1), 16-19. https://doi.org/10.1108/DLO-09-2013-0072

Susan, K. (2009). Core Competencies of Large Church Leadership, (1).

Toliver, Y. (2017). Succession Planning for Next Generation Business Leaders, 131.

Diambil dari https://scholarworks.waldenu.edu/dissertations

Younger, K. L. J. (2000). Joshua. In Eerdmans Dictionary of the Bible. W.B. Eerdmans.

Yukl, G. (2012). Effective leadership behavior: What we know and what questions need more attention. Academy of Management Perspectives, 26(4), 66-85.

https://doi.org/10.5465/amp.2012.0088 